\title{
PLACING THE COMMUNITY AT THE HEART OF ISLAND GOVERNANCE: THE ISLANDS (SCOTLAND) ACT 2018
}

\author{
Francesco Sindico and Nicola Crook ${ }^{1}$
}

\section{A. INTRODUCTION}

The adoption of the Islands (Scotland) Act 2018 (the Act) ${ }^{2}$ in July 2018 marked a historical moment for island communities in Scotland. The provisions therein, and their implementation, provide a unique opportunity for island communities to influence the agenda of the Scottish Government in relation to island governance. The Act has the potential to position Scotland at the forefront of island law and policy on an international scale. This paper expands on this opportunity by providing a snapshot of the journey that has led to the Act. It will then discuss the National Islands Plan and the provision requiring island communities impact assessment to be undertaken, both of which are key elements present in the Act. The paper concludes by drawing attention to the Act's emphasis on island communities. When it comes to island law and policy, Scotland will only be able to claim true leadership if it carries through its commitments towards island communities in the implementation of the Act.

\section{B. FROM OUR ISLANDS, OUR FUTURE TO THE ISLANDS (SCOTLAND) ACT 2018}

In June 2013, Comhairle nan Eilean Siar (the Western Isles Council), Orkney Islands Council and Shetland Islands Council launched the Our Islands - Our Future campaign, ${ }^{3}$ with the aim of ensuring that the needs and status of island areas in Scotland were clearly recognised. Although this was written in the context of a potentially independent Scotland, the Scottish Government went on to form the Island Areas Ministerial Working Group, which focused on three key areas: 1) how the Islands councils are and can be supported to use existing powers available to them and engage communities to deliver improved, more responsive public services and better outcomes for communities; 2) consider the development and extension of local democracy in the island groups and opportunities in the context of the 2014 Scottish independence referendum, including the issues raised by the Our Islands - Our Future

\footnotetext{
*Francesco Sindico is a Reader in International Environmental Law at the University of Strathclyde Law School and Co-Director of the Strathclyde Centre for Environmental Law and Governance. Nicola Crook is a PhD Researcher at the Strathclyde Centre for Environmental Law and Governance, focusing on law and policy in relation to community participation on Scottish Islands. Both Francesco and Nicola are providing technical assistance to Scottish Government in the development of the National Islands Plan and in work around island communities impact assessment. This article reflects their personal opinions and does not reflect in any way the position of Scottish Government.

${ }^{2}$ Islands (Scotland) Act 2018 [2018 Act]

3 Our Islands, Our Future, Joint Position Statement. Available at: https://www.cnesiar.gov.uk/media/7964/jointpositionstatement.pd
} 
joint position statement; and 3) agree a prospectus outlining opportunities for island communities in the future.

In June 2014, on conclusion of the Island Areas Ministerial Working Group's work, the Scottish Government published the Empowering Scotland's Island Communities prospectus, ${ }^{4}$ presented as a coherent package of measures that developed a set of proposals based on three underpinning objectives: 1) Promoting the voice of island communities; 2) harnessing island resources; and 3) enhancing the wellbeing of island communities.

As a result, the UK Government adopted a Framework for the Islands ${ }^{5}$ where it developed 'island proofing' as a principle, whereby policy and legislation must take into account islands' circumstances. Following the Empowering Scotland's Island Communities prospectus, the Scottish Government consulted on provisions for a future Islands Bill. A key focus of this consultation was the aspect of 'island-proofing', with a focus on its inclusion as a principle within any future Island Bills to formalise the approach in legislation. As a result, the Islands (Scotland) Bill 2018 was passed and received Royal Assent on 6 July 2018. The first Commencement Regulations for the Island Act were laid on 20 September 2018 and came into force on 4 October 2018.

The Islands (Scotland) Act 2018 intends to provide a normative space for islands and island communities within the Scottish legal system. Scottish island communities have too often been left on the side lines when it comes to law and policy. The Act seeks to rectify this by providing a concrete opportunity for island communities to have their concerns heard and interests fully taken into account. It does so, in particular, through two key provisions present in the Act: the National Islands Plan and the islands communities impact assessment.

\section{ISLAND COMMUNITIES AND THE NATIONAL ISLANDS PLAN}

The Islands (Scotland) Act mandates Scottish Ministers to present to Parliament a National Islands Plan by 4 October 2019. ${ }^{6}$ The Plan will highlight strategies and objectives that Scottish Government will need to take forward in order to improve outcomes for island communities. ${ }^{7}$ One possibility could have been to draw up a Plan and then present it for consultation to island communities. Fortunately, the Act took a rather different approach and Scottish Government is obliged to undertake a consultation that will inform the content of the National Islands Plan. ${ }^{8}$ The latter will be shaped by the voices of the different island communities consulted. ${ }^{9}$ However, the Act

\footnotetext{
4 Scottish Parliament, Official Report, Island Areas Ministerial Working Group, Prospectus, Empowering Scotland's Island Communities, June 2014.

${ }^{5}$ UK Government and the three Scottish Island Councils, Framework for the Islands, 2014. Available at: https://assets.publishing.service.gov.uk/government/uploads/system/uploads/attachment data/file/344446/ UKG ISLANDS FRAMEWORK - 15 August.pdf

${ }^{6}$ Islands (Scotland) Act 2018 s 4(2).

${ }^{7} 2018$ Act s 3(2).

82018 Act s 4(1)(a).

9 The authors are part of the Strathclyde Centre for Environmental Law and Governance that is providing technical advice to the Scottish Government in the above-mentioned consultation process. The latter is
} 
does provide some guidance in relation to outcomes for island communities that the Plan will need to address. Section 3(3) lists the following aspects as areas that will need to be improved:

(a) increasing population levels,

(b) improving and promoting-

(i) sustainable economic development,

(ii) environmental wellbeing,

(iii) health and wellbeing, and

(iv) community empowerment,

(c) improving transport services,

(d) improving digital connectivity,

(e) reducing fuel poverty,

(f) ensuring effective management of the Scottish Crown Estate (that is, the property, rights and interests to which section 90B(5) of the Scotland Act 1998 applies),

(g) enhancing biosecurity (including protecting islands from the impact of invasive non-native species).

However, for the Plan to work effectively, it is crucial to avoid the pitfall of focusing solely on one specific area whilst failing to acknowledge its interdependent relationship with others. A silos approach would be a recipe for failure. What is needed is an integrated and holistic approach that acknowledges that different aspects of island communities work together and are reliant on one another. There is a need to ensure that policies understand the interaction between all aspects of island life.

Furthermore, while no areas and sectors are more important than others, due to the aforementioned integrated nature of island life, some areas have stronger transformational potential. Three of these areas are housing, digital connectivity and transport. ${ }^{10}$ All three of these sectors should not be seen as economic services responding only to market forces. They are lifelines of island communities and should be treated as such. We could go as far as to consider that, in some way, they should

organised using a world café methodology format that enables the island community members present to the consultation to engage in a participative discussion about what works well on their island, what should be improved and also allows for some areas to be discussed in more depth enabling participants to share their solutions to the problems faced by their islands. During the consultation, the team has visited 43 islands and organised 68 events. The consultation is complemented by an on-line consultation where participants can raise similar issues electronically. The consultation process is led by the Scottish Government Islands Team and has benefited from the facilitation of Sandy Burnton, Head of the Mull and lona Community Trust and the support of the Scottish Islands Federation.

${ }^{10}$ These observations are taken from an initial interim report from the consultation prepared by the two authors and presented to Scottish Government cross sector policy officials at an event in Edinburgh on 29 May 2019 [presentation on file with authors]. 
be rights that island communities enjoy and that should be protected. A shift in the discourse from the needs of island communities to rights and from responsibilities of those providing specific services to duties aligns with policy developments within Scotland. In fact, in December 2018, the First Minister's Advisory Group on Human Rights Leadership published its 'Recommendations for a new human rights framework to improve people's lives'. ${ }^{11}$ One of the recommendations is to develop "[A]n act of Scottish Parliament which provides human rights leadership". ${ }^{12}$ In order to prepare such an Act, the Advisory Group made a second recommendation according to which an effective participatory process needs to take place so that communities duly inform its preparation and implementation across Scotland. ${ }^{13}$ It is paramount that island communities are given a chance to be part of this process.

This rights approach would require the Scottish Government to open a debate between island communities and providers where rights and responsibilities must be on the table. From a practical perspective, this shift in discourse implies that maximum available resources should be used for the progressive realisation of human rights, which calls for deliberate concrete steps to progressively realise these rights. A rights approach to the National Islands Plan has the potential to give island communities greater community empowerment and make Scottish Government more accountable in the implementation of the National Islands Plan.

\section{ISLAND COMMUNITIES IMPACT ASSESSMENT}

The second provision that aims to give island communities a stronger voice in relation to policy is the obligation to undertake an island communities impact assessment. ${ }^{14}$ The latter should take place when a piece of legislation, strategy or service will likely affect island communities in a different way than how it would affect communities on the mainland or other island communities. ${ }^{15}$ While guidance on the impact assessment still needs to be developed, ${ }^{16}$ the provision itself provides a tangible and more immediate opportunity for the islands to have their views heard in a formal process in relation to decisions taken that affect them in a disproportionate manner. Strategic environmental assessments could be used as models to build and develop island communities impact assessment. ${ }^{17}$ However, previous examples, even those that

\footnotetext{
${ }^{11}$ Scottish Parliament, Official Report, First Minister's Advisory Group on Human Rights Leadership, Recommendations for a new human rights framework to improve people's lives, Report to the First Minister, December 2018. Available at: https://humanrightsleadership.scot/wp-content/uploads/2018/12/FirstMinisters-Advisory-Group-on-Human-Rights-Leadership-Final-report-for-publication.pdf

12 Ibid, Recommendation 1.

13 Ibid, Recommendation 2.

142018 Act s 8.

${ }^{15} 2018$ Act s 8(1): “A relevant authority must prepare an island communities impact assessment in relation to a- (a)policy, (b)strategy, or (c)service, which, in the authority's opinion, is likely to have an effect on an island community which is significantly different from its effect on other communities (including other island communities) in the area in which the authority exercises its functions."

162018 Act s 11.

${ }^{17}$ Strategic environmental assessments were first introduced in 1969 with the National Environmental Policy Act in the United States of America. In the European context, the European Union has adopted Directive 2001/42/EC on Strategic environmental assessments. On the latter see A. Polido, E. Joao and T.B. Ramos, "Sustainability
} 
worked for island communities elsewhere, will need to be tweaked and nuanced since context is a crucial element when it comes to impact assessment. ${ }^{18}$ Furthermore, island communities impact assessment will have a much broader remit than strategic 'environmental' assessments.

Whatever format the island communities impact assessment will take at the end, it is important that it aligns itself with the latest trends in impact assessment. For example, rather than "treating the assessment process components as hoops for proponents to jump through to gain project approval, IA [impact assessment] must be centred on learning, building a culture of sustainability, and serving the long - as well as short term public interest." 19

An important part of the Islands (Scotland) Act is the possibility to review decisions related to island communities impact assessment. ${ }^{20}$ Regulations still need to be developed detailing, amongst other things, who will have the power to challenge impact assessment decisions. If island communities, or representatives thereof, are included amongst such actors, the Islands (Scotland) Act will become a concrete opportunity to shift public policy discourse in Scotland from the mainland to island communities and will align itself with the emerging discourse in impact assessment that calls on greater accountability and community empowerment. ${ }^{21}$

\section{E. SCOTLAND LEADING THE WAY}

The Islands (Scotland) Act is one of very few pieces of legislation around the world that focuses specifically on islands within a country and on its communities. ${ }^{22}$ There is a concrete possibility for Scottish Government to position itself as a global leader in this field, as it has done in others. ${ }^{23}$ However, it will be the implementation of the

approaches and strategic environmental assessment in small islands: An integrative review", 96 Ocean \& Coastal Management (2014), 138-148, 140.

18 Just like for Strategic environmental assessment, which is "context specific and needs to be developed taking this into account"; A. Polido, et al,, "Sustainability approaches and strategic environmental assessment in small islands: An integrative review", 96 Ocean \& Coastal Management (2014), 138-148, 139, referring to a study by T. Hilding-Rydevik and H. Bjarnadottir, "Context awareness and sensitivity in SEA implementation" 27 Environmental Impact Assessment (2007), 666-684.

${ }^{19}$ A.J. Sinclair, et al., "Implementing next generation assessment: A case example of a global challenge", 72 Environmental Impact Assessment Review (2018), 166-176, 171.

202018 Act s 9: "(1)The Scottish Ministers must by regulations make provision about reviews of decisions of relevant authorities relating to island communities impact assessments under section 8(1). (2) Regulations under subsection (1) may, in particular, make provision about- (a) the procedure to be followed in connection with reviews, (b) the manner in which reviews are to be conducted, (c) the time limits within which applications for reviews are to be made, (d) the circumstances under which applications for reviews may or may not be made, (e) the persons to whom applications for reviews may be made, and (f) the steps that may be taken by a relevant authority following a review."

${ }^{21}$ A.J. Sinclair, et al., "Implementing next generation assessment: A case example of a global challenge", 72 Environmental Impact Assessment Review (2018), . 166-176, 171-173.

22 The Islands Act, as passed by the Croatian Parliament, is one such example. Available at: http://www.globalislands.net/greenislands/docs/croatia 080306-islands-act.pdf

${ }^{23}$ The Climate Justice showcases leadership in the fields of climate change and international development (more information available at https://www.gov.scot/policies/international-development/climate-justice-fund/) and 
Islands (Scotland) Act that will determine whether the work that has now started can really be hailed as a good practice going forward. The National Islands Plan will most likely draw the attention of central government to the specific and sometimes unique demands of island communities in numerous sectors. For islands to increase their population (where needed and wanted) and to promote sustainable economic development, a change in mind-set has to stem from the National Islands Plan; policies may well have to start from the periphery rather than being city and central belt oriented. While the interest of island communities may not necessarily come first, it cannot be ignored anymore. However, for this to occur, three things must happen.

Firstly, Scottish Government will have to take action where the Plan requires it to do so. It will not be just a question of finance, but of opening a genuine and longterm channel of communication between central government and island communities.

Secondly, island communities will need to be convinced that the Plan does indeed respond to their interests and was informed by their views. A genuine consultation process is the first step towards allowing the island communities to feel that they own they plan and are be aware of its potential. However, more actions have to take place once the Plan is adopted and launched, in order to promote the Plan and make it accessible to all sectors of island communities.

Finally, island communities will need to keep Scottish Government to account. It will be important that they focus their attention on the annual reporting required by the Islands (Scotland) Act according to which Scottish Government will have to report on the progress (or lack of) on the implementation of the National Islands Plan. ${ }^{24}$ It is also important to remember that every four years the National Islands Plan will be reviewed. ${ }^{25}$ Accountability will also be important in relation to the island communities impact assessment, hence the importance of giving island communities a voice in decisions related to the review of island communities impact assessment.

\footnotetext{
the Hydronation marks Scotland's leadership in the field of integrated water resources management (more information available at https://www.gov.scot/policies/water/hydro-nation/).

242018 Act s 5: “(1) The Scottish Ministers must prepare a report for each reporting year, containing information - (a) about the extent to which the outcomes identified in the national islands plan have improved in the reporting year, (b) about steps the Scottish Ministers will take where an outcome identified in the national islands plan has not improved in the reporting year, (c) about the steps which the Scottish Ministers have taken to comply with the duties in relation to island communities imposed by- (i) section 7 (including any island communities impact assessment prepared under section 8), and (ii) section 13, and(d)about any other matters which the Scottish Ministers consider appropriate. (2) In this section, "reporting year" means the period of one year beginning - (a) in the case of the first report following each publication of a national islands plan under section 4(4), with the day on which the national islands plan is published, (b) in any other case, with the day of the expiry of the last period of one year. (3)Before the end of the period of 3 months beginning with the last day of the reporting year, the Scottish Ministers must- (a) lay the report before the Scottish Parliament, and (b) publish the report."

${ }^{25} 2018$ Act s 6: "(1)The Scottish Ministers-(a) must review the national islands plan before the end of the period of 5 years beginning with the day on which the plan was last published, and (b)may from time to time review the plan. (2) Following a review under subsection (1), the Scottish Ministers may revise the plan as they consider appropriate. (3) Subsections (1), (3) and (4) of section 4 apply to a review of the plan under subsection (1) as they apply to the preparation of the plan under that section."
} 
Only if these three aspects are duly considered and taken forward (change in mindset from central government, a genuine understanding and ownership of the Plan on behalf of island communities and systems of accountability to keep track of the implementation of the Islands (Scotland) Act and provisions therein) will Scotland become a leader in the field of island law and policy.

\section{F. CONCLUSION}

Two final observations conclude this short paper. Firstly, islands and island communities in Scotland are, by definition, rural places. They share many similar facets and traits with rural areas across Scotland. Rather than re-opening a discussion on why rural areas were not included in the Act, or why islands were not just grouped with rural areas, the Islands (Scotland) Act presents an opportunity. This time not only for island communities, but also for rural communities on the mainland. The implementation of the Islands (Scotland) Act presents an opportunity to develop good practices in terms of genuine input into a nation-wide Plan that covers such distinct realities, ${ }^{26}$ specifically in relation to the field of impact assessment and good practices related to holding government to account. If these indeed become good practices, they could, and should, be considered as a potential way forward by rural communities on the mainland, albeit tweaking them to their own interests and specific circumstances.

The second final observation is the concept of island communities to which this paper and the Act refer. The latter provides a very broad definition according to which:

"island community" means a community which-

(a) consists of two or more individuals, all of whom permanently inhabit an island (whether or not the same island), and

(b) is based on common interest, identity or geography (including in relation to any uninhabited island whose natural environment and terrestrial, marine and associated ecosystems contribute to the natural or cultural heritage or economy of an inhabited island). . ${ }^{27}$

However, is this feasible in the implementation of the Act? Can every two people who share such characteristics be considered an island community, for example, in the possible review of decisions related to impact assessment? Another option is to start looking into island based local democracy, exploring the role of community councils and local community groups and organisations. Once again, the Act and the National Islands Plan provides an opportunity, not so much to come up with an immediate solution, but indeed to open a fresh discourse that takes these

\footnotetext{
${ }^{26}$ The Islands (Scotland) Act requires Scottish Ministers to prepare one plan but in doing so they must "have regard to the distinctive geographical, natural heritage and cultural characteristics (including the linguistic heritage) of each of the areas inhabited by island communities, 2018 Act s 4(1)(b). The reality is that all Scottish islands are unique in one way or another and if adopting one Plan implies a one size fits all approach, the Plan and the Islands (Scotland) Act will not be successful.
}

272018 Act s 2. 
questions away from a merely theoretical and academic debate, into a more practical dimension linked to the implementation of the Islands (Scotland) Act 2018.

In conclusion, from Arran to Unst, the Islands (Scotland) Act is a story of opportunities. The implementation of the Act will tell us if it is a story of a missed opportunity, or a story of one that was embraced and taken forward in the interest of all the island communities of Scotland. 